PERTANIAN

\title{
ESTIMASI TOTAL AIR TERSEDIA BAGI TANAMAN PADA BERBAGAI TEKSTUR TANAH MENGGUNAKAN METODE PENGUKURAN KANDUNGAN AIR JENUH
}

\author{
Estimation of Total Available Water for Plants in Various Soil Textures Using \\ the Saturated Water Content Measurement Method
}

Fitria Dwi Darmayati* dan Tarsicius Sutikto

\author{
Program Studi Agroteknologi, Fakultas Pertanian, Universitas Jember \\ J1. Kalimantan 37, Kampus Tegal Boto, Jember 6812 \\ *E-mail: fitriadarmayati@yahoo.com
}

\begin{abstract}
This research was about determine the water content using the method of saturated water content that has been carried out and were suitable in Canada, However, this method needs to be tested for tropical regions such as in Jember. This present study aimed to determine the accuracy and characteristics of the empirical equations that used in determine the water content using the method of saturated water content in several classes of soil texture. Soil samples consist of the Raung Mountains, Argopuro Mountains, and Southern Mountains zones which are expected to represent several texture classes. The empirical equation is $Y_{\mathrm{fc}}$ $=\mathrm{a}+\mathrm{b}\left(\mathrm{x}_{\mathrm{fc}}\right)$, to determine the water content in the field capacity condition, $\mathrm{Y}_{\mathrm{w}}=\mathrm{a}+\mathrm{b}\left(\mathrm{x}_{\mathrm{w}}\right)$, to determine the water content in $\mathrm{a}$ permanent wilt point condition. The empirical equation for total available water is $A T=Y_{f c}-Y_{w}$. Based on the results of the study obtained a new equation from the results regression analysis of the saturated water content value with the measurements of Pressure Plate Apparatuse results, named $\mathrm{Y}_{\mathrm{fc}}=-2.4742+0.6551$ (x) and $\mathrm{Y}_{\mathrm{w}}=-16.949+0.557$ (x). From the equation, then determined total available water based on the Karkanis Equation and the New Equation. The appropriateness test of the method of saturated water content using Graph 1: 1 was carried out on each total available water data (Karkanis equation and new equation) which results showed that the method was invalid to be applied to the study location $\left(\mathrm{R}^{2}=0.0239\right)$.
\end{abstract}

Key words: Total Available Water, Soil Texture, Pressure Plate Apparatus, Saturated Water Content

\begin{abstract}
ABSTRAK
Penelitian mengenai penetapan kandungan air menggunakan metode pengukuran kandungan air jenuh telah dilakukan di Canada hasilnya sesuai untuk daerah tersebut. Namun metode tersebut perlu diuji untuk daerah tropika seperti di Jember. Penelitian ini dilakukan untuk mengetahui akurasi dan karakteristik persamaan empiris yang digunakan dalam penetapan total air tersedia dengan metode kandungan air jenuh pada beberapa kelas tekstur tanah. Contoh tanah terdiri atas zona Pegunungan Raung, Pegunungan Argopuro, dan Pegunungan Selatan yang diharapkan mewakili beberapa kelas tekstur. Persamaan empiris yang digunakan adalah $\mathrm{Y}_{\mathrm{fc}}=\mathrm{a}+\mathrm{b}\left(\mathrm{x}_{\mathrm{fc}}\right)$, untuk kandungan air kapasitas lapang, $\mathrm{Y}_{\mathrm{w}}=\mathrm{a}+\mathrm{b}\left(\mathrm{x}_{\mathrm{w}}\right)$, untuk kandungan air titik layu permanen. Persamaan empiris untuk total air teredia yaitu $A T=Y_{\mathrm{fc}}-\mathrm{Y}_{\mathrm{w}}$. Hasil dari penelitian diperoleh Persamaan Baru dari hasil analisis regresi nilai kandungan air jenuh dengan hasil pengukuran Pressure Plate Apparatuse yaitu $\mathrm{Y}_{\mathrm{fc}}=-2,4742+0,6551$ (x) dan $\mathrm{Y}_{\mathrm{w}}=-16,949+0,557(\mathrm{x})$. Dari persamaan tersebut kemudian ditentukan total air tersedia berdasarkan Persamaan Karkanis dan Persamaan Baru. Uji kelayakan metode pengukuran kandungan air jenuh dengan menggunakan Grafik 1:1 dilakukan pada masing-masing data total air tersedia (Persamaan Karkanis dan Persamaan baru) yang hasilnya menunjukkan bahwa metode tersebut tidak valid/sahih untuk diterapkan pada lokasi penelitian $\left(\mathrm{R}^{2}=0,0239\right)$.
\end{abstract}

Kata Kunci : Total Air Tersedia, Tekstur tanah, Pressure Plate Apparatus, Kandungan Air Jenuh.

How to citate: Darmayati, F. D.. dan T. Sutikto. 2019. Estimasi Total Air Tersedia Bagi Tanaman Pada Berbagai Tekstur Tanah Menggunakan Metode Pengukuran Kandungan Air Jenuh. Berkala Ilmiah Pertanian 2(4): 164-168.

\section{PENDAHULUAN}

Secara umum air tersedia adalah selisih kandungan air pada kapasitas lapang dan titik layu permanen yang dapat dijadikan acuan dalam melakukan penjadwalan irigasi pada proses budidaya. Kandungan air kapasitas lapang merupakan persentase kandungan air yang ditahan oleh tanah pada retensi 0,1 hingga 0,5 atm, sedangkan titik layu permanen merupakan kandungan air tanah yang dipegang oleh tanah dengan retensi 15 atm. (Karkanis, 1983). Kandungan air pada kapasitas lapang dan titik layu dipengaruhi oleh tekstur tanah dan beberapa karakteristik lainnya. Tekstur tanah berhubungan dengan total pori tanah sehingga dapat mempengaruhi total air tersedia bagi tanaman.
Penetapan kandungan air kapasitas lapang dan titik layu permanen umumnya dilakukan dengan menggunakan Pressure Plate Apparatus (tekanan $30 \mathrm{kPa}$ dan tekanan $1500 \mathrm{kPa}$. Penggunaan alat tersebut memiliki beberapa kelemahan, diantaranya adalah tergolong mahal, waktu yang dibutuhkan untuk analisis relatif lama dan contoh tanah yang digunakan merupakan contoh tanah utuh dalam ring sample. Beberapa peneliti mencoba melakukan pengukuran kandungan air pada kapasitas lapang dan titik layu permanen dengan pengukuran kandungan air dengan kandungan air jenuh, misalnya Veihmeyer and Hendrickson (1949), Longenecker and Lyerly (1964) dan Karkanis (1983).

Pada hasil penelitian yang dilakukan oleh Karkanis (1983), penetapan kapasitas lapang dan titik layu menggunakan metode kandungan air jenuh dengan kenaikan kapiler dinyatakan akurat. 
Penelitian tersebut dilakukan dengan menggunakan contoh tanah yang dihancurkan (terusik) sehingga dengan mudah menyerap air melalui kenaikan kapiler sampai keadaan jenuh. Penetapan persentase kandungan air tanah dihitung dengan menggunakan persamaan empiris yang berbeda untuk perhitungan kapasitas lapang dan titik layu permanen.

Penelitian "Estimasi Total Air Tersedia Bagi Tanaman pada Berbagai Tekstur Tanah menggunakan Metode Pengukuran Kandungan Air Jenuh" dilakukan untuk mengetahui akurasi persamaan empiris yang digunakan dalam penetilian Karkanis (1983). Tanah tropika memiliki karakteristik yang berbeda dengan tanah non tropika, salah satunya adalah kemampuan mengikat air. Oleh karena itu estimasi kandungan air pada kapasitas lapang dan titik layu permanen menggunakan metode pengukuran kandungan air jenuh perlu diuji dan diharapkan dapat diaplikasikan dengan tepat dan sesuai untuk tekstur tanah di daerah tropika, khususnya wilayah Jember

\section{BAHAN DAN METODE}

Tempat dan Waktu: Penelitian ini dilaksanakan pada bulan Juli 2018 - November 2018, contoh tanah diambil dari beberapa wilayah kecamatan di Kabupaten Jember (9 Kecamatan) yang mencakup Pegunungan Raung, Pegunungan Argopuro dan Pegunungan Selatan.

Bahan: Contoh tanah berasal dari zona Pegunungan Raung, Pegunungan Argopuro dan Pegunungan Selatan, bahan-bahan kimia yang di butuhkan untuk analisis tekstur $\left(\mathrm{H}_{2} \mathrm{O}_{2} 30 \%\right.$ dan $\mathrm{Na}_{2} \mathrm{PO}_{4} \mathrm{O}_{7}$ $0,2 \mathrm{~N})$, dan kertas filter Whatman no.1.

Alat: Ring sample, ayakan $0,05 \mathrm{~mm}$, pipet apparatus, Pressure plate apparatus, tabung sedimen $1000 \mathrm{ml}$, dan oven

Prosedur Penelitian sebagai berikut:

Pengambilan Contoh Tanah. Contoh tanah diambil dari beberapa zona Pegunungan Raung, Pegunungan Argopuro dan Pegunungan Selatan. Contoh tanah diambil menggunakan ring sample dan dalam bentuk terusik pada kedalaman $0-15 \mathrm{~cm}$ dari permukaan tanah.

Analisis Contoh Tanah di Laboratorium. Analisis contoh tanah di laboratorium meliputi: a). Pengukuran kapasitas lapang dan titik layu permanen menggunakan Pressure Plate Apparatus, b). Pengukuran kandungan air metode kandungan air jenuh, c). Tekstur tanah, d). Berat volume tanah, dan e). Kandungan air $(\theta)$.

Analisis Data Hasil Penelitian. Menurut Karkanis (1983) persamaan empiris kandungan air pada kapasitas lapang dan titik layu permanen dinyatakan sebagai berikut :

$\mathrm{Yfc}=-51,45856+(1,54695)(\mathrm{x}) ; \mathrm{R}^{2}=0,92740$

$\mathrm{YW}_{\mathrm{W}}=-35,16769+(0,99733)(\mathrm{x}) ; \mathrm{R}^{2}=0,92740$

Keterangan :

$\mathrm{Y}_{\mathrm{fc}}=$ persamaan untuk menentukan kapasitas lapang

$\mathrm{Y}_{\mathrm{w}} \quad=$ persamaan untuk menentukan titik layu permanen

$\mathrm{x} \quad=$ nilai kandungan air.

Analisis regresi dilakukan pada data kadar air kapasitas lapang dan titik layu permanen sehingga diperoleh persamaan empiris baru yang sesuai untuk tanah di wilayah penelitian. Persamaan umumnya adalah:

$\mathrm{Y}_{\mathrm{fc}}=\mathrm{a}+\mathrm{b}(\mathrm{x})$

$Y_{\mathrm{w}}=\mathrm{a}+\mathrm{b}(\mathrm{x})$

\section{Keterangan: $\quad \mathrm{a}=$ konstanta ; \\ $\mathrm{b}=$ koefisien regresi; \\ $\mathrm{x}=$ nilai kandungan air}

Dari Persamaan 1.3 dan 1.4 kemudian dihitung total air tersedia bagi tanaman, sebagai berikut:

$\mathrm{AT}=\mathrm{Yfc}-\mathrm{Yw}$

Keterangan:

AT $=$ total air tersedia bagi tanaman

Yfc = persamaan untuk menentukan kapasitas lapang

$\mathrm{Yw}=$ persamaan untuk menentukan titik layu permanen
Kelayakan Persamaan 1.3 dan 1.5 diuji dengan memasukkan data hasil pengukuran kandungan air jenuh, kemudian membandingkan dengan data pengukuran menggunakan Pressure Plate Apparatus. Tingkat akurasi dan karakteristik metode pengukuran kandungan air jenuh pada masing-masing tekstur tanah penelitian dianalisis menggunakan Grafik garis 1:1.

\section{HASIL DAN PEMBAHASAN}

\section{Gambaran Umum Lokasi Penelitian}

Kabupaten Jember terletak di bagian timur wilayah Provinsi Jawa Timur, tepatnya berada pada posisi $7^{\circ} 59^{\prime} 6^{\prime \prime}-8^{\circ} 33^{\prime} 56^{\prime \prime}$ LS dan $113^{\circ} 16^{\prime} 28^{\prime \prime}-114^{\circ} 03^{\prime} 42^{\prime \prime}$ BT dengan luas wilayah $\pm 3.293,34 \mathrm{~km}^{2}$. Kabupaten Jember berada pada ketinggian 0-3.300 mdpl, dengan ketinggian daerah perkotaan Jember kurang lebih 87 meter di atas permukaan laut (mdpl). Secara administratif wilayah Kabupaten Jember terbagi menjadi 31 kecamatan (Imawati, 2009).

\section{Lokasi Pengambilan Contoh Tanah dan Kelas Tekstur Tanah}

Contoh tanah diambil di 9 wilayah kecamatan dan masingmasing kecamatan diambil 3 contoh tanah. Ke 9 kecamatan tersebut menggambarkan tiga kawasan yaitu kawasan Raung (Silo, Kalisat dan Mayang), kawasan Argopuro (Panti, Jelbuk, Bangsalsari dan Kaliputih) dan kawasan Pegunungan Selatan (Glantangan dan Tempurejo).

Tekstur tanah masing-masing lokasi berkisar antara Sandy Loam, Sandy Clay Loam, Clay Loam dan Loam. Secara garis besar tekstur tanah lokasi penelitian tergolong dalam kelas loam dengan kandungan klei berkisar antara $9-36 \%$. Menurut Intara dkk. (2011), bahwa tekstur tanah klei dapat menyimpan air lebih banyak. Tanah bertekstur klei tidak hanya memiliki permukaan yang luas tetapi juga bermuatanlistrik. Muatan listrik memberi sifat pada klei untuk dapat mengikat air maupun hara tanaman pada permukaannya.

Menurut Mahida (1984) tanah klei sebagai campuran partikelpartikel pasir dan debu dengan bagian-bagian tanah klei yang mempunyai sifat-sifat karakteristik yang berlainan. Salah satu ciri partikel-partikel tanah klei yaitu mempunyai muatan ion positif yang dapat dipertukarkan. Material tanah klei mempunyai daya serap yang baik terhadap perubahan kadar kelembapan (kandungan air) karena tanah klei mempunyai luas permukaan yang sangat besar.

Berat volume tanah (BV) adalah perbandingan antara berat tanah kering dengan volume tanah termasuk volume pori pori tanah. Berat volume tanah dapat dijadikan sebagai petunjuk kepadatan tanah. Makin padat suatu tanah, makin tinggi berat volume tanah yang berarti permeabilitas tanah semakin rendah. Tanah lapisan atas yang bertekstur liat mempunyai berat volume tanah berkisar antara $1,0-1,3 \mathrm{~g} / \mathrm{cm} 3$, sedangkan yang bertekstur kasar mempunyai berat volume tanah antara 1,3-1,8 g/cm3 (Hanafiah, 2005). Berat volume tanah dipengaruhi oleh struktur tanah, pengolahan tanah, kandungan bahan organik dan agregasi tanah (proses pembentukan agregat tanah).

\section{Kandungan Air Kapasitas Lapang dan Titik Layu Permanen}

Kapasitas lapang merupakan keadaan tanah yang cukup lembab yang menunjukkan jumlah air terbanyak yang dapat ditahan oleh tanah terhadap gaya tarik gravitasi. Air yang dapat ditahan oleh tanah tersebut terus menerus diserap oleh akar-akar tanaman atau menguap sehingga tanah makin lama semakin kering. (Siregar dkk., 2017).

Salah satu faktor yang mempengaruhi kandungan air dalam tanah adalah sebaran pori. Menurut Wahjunie dkk. (2008) pori tanah yang banyak berkaitan dengan pergerakan air secara cepat adalah pori makro dan meso. Jumlah air yang masuk dan tertinggal dalam tanah ditentukan oleh kemampuan retensi tanah dan pergerakan air dalam tanah. Pada potensial air tanah rendah ( $\psi \leq 1$ bar), kadar air tanah sangat ditentukan oleh kapilaritas dan distribusi ukuran pori tanah. Pada potensial yang lebih tinggi, kadar air tanah lebih ditentukan oleh tekstur tanah. Menurut Lubis (2007) faktor-faktor yang mempengaruhi energi potensial air tanah yakni adsorpsi air 
oleh partikel tanah, pelarut yang melarutkan dalam air tanah, elevasi air tanah pada lahan gravitasi bumi, tekanan yang dibuat (positif dan negatif).

Hasil penjenuhan contoh tanah yang dilakukan dengan menggunakan sistem Syphone Mariotte selama 3,5 jam berupa nilai kandungan air pada masing-masing contoh tanah. Data hasil penjenuhan tersebut kemudian di regresikan dengan data hasil pengukuran menggunakan Pressure Plate Apparatus untuk memperoleh persamaan. Berikut merupakan Persamaan Karkanis yang digunakan:

$\mathrm{Y}_{\mathrm{fc}}=-51,45856+(1,54695)(\mathrm{x}) ; \mathrm{R}^{2}=0,92740$

$Y_{\mathrm{w}}=-35,16769+(0,99733)(\mathrm{x}) ; \mathrm{R}^{2}=0,92740$

Tabel 1.1 Kandungan Air Kapasitas Lapang dan Titik Layu Permanen

\begin{tabular}{|c|c|c|c|c|c|c|c|c|}
\hline \multirow{2}{*}{ Zona } & \multirow{2}{*}{ Lokasi } & \multirow{2}{*}{$\begin{array}{l}\text { Kadar Air } \\
\text { Metode } \\
\text { Penjenuhan } \\
(\theta)\end{array}$} & \multicolumn{2}{|c|}{ Persamaan Karkanis } & \multicolumn{2}{|c|}{ Persamaan Baru } & \multicolumn{2}{|c|}{$\begin{array}{c}\text { Pengukuran dengan Pressure } \\
\text { Plate Apparatus }\end{array}$} \\
\hline & & & $\mathrm{pF} 2,5$ & $\mathrm{pF} 4,2$ & $\mathrm{pF} 2,5$ & $\mathrm{pF} 4,2$ & $\mathrm{pF} 2,5$ & $\mathrm{pF} 4,2$ \\
\hline \multirow{9}{*}{$\begin{array}{l}\text { Pegunungan } \\
\text { Raung }\end{array}$} & Silo 1 & 64,33 & 48,06 & 28,99 & 39,67 & 18,88 & 29,04 & 16,94 \\
\hline & Silo 2 & 66,91 & 52,04 & 31,56 & 41,36 & 20,32 & 39,68 & 17,36 \\
\hline & Silo 3 & 65,65 & 50,10 & 30,31 & 40,53 & 19,62 & 38,28 & 17,40 \\
\hline & Kalisat 1 & 72,95 & 61,39 & 37,59 & 45,32 & 23,68 & 46,36 & 18,30 \\
\hline & Kalisat 2 & 67,11 & 52,36 & 31,77 & 41,49 & 20,43 & 39,99 & 21,93 \\
\hline & Kalisat 3 & 68,12 & 53,91 & 32,77 & 42,15 & 20,99 & 49,95 & 17,76 \\
\hline & Mayang 1 & 55,50 & 34,40 & 20,19 & 33,89 & 13,97 & 39,96 & 15,12 \\
\hline & Mayang 2 & 68,11 & 53,90 & 32,76 & 42,14 & 20,99 & 41,20 & 20,60 \\
\hline & Mayang 3 & 67,61 & 53,13 & 32,26 & 41,82 & 20,71 & 42,50 & 16,25 \\
\hline \multirow{11}{*}{$\begin{array}{l}\text { Pegunungan } \\
\text { Argopuro }\end{array}$} & Panti 1 & 80,08 & 72,42 & 44,70 & 49,99 & 27,66 & 62,10 & 28,75 \\
\hline & Panti 2 & 89,13 & 86,43 & 53,73 & 55,92 & 32,70 & 54,72 & 23,94 \\
\hline & Jelbuk 1 & 83,27 & 77,35 & 47,88 & 52,07 & 29,43 & 49,61 & 36,30 \\
\hline & Jelbuk 2 & 88,45 & 85,37 & 53,05 & 55,47 & 32,32 & 53,32 & 24,80 \\
\hline & Jelbuk 3 & 74,31 & 63,50 & 38,95 & 46,21 & 24,44 & 48,40 & 26,62 \\
\hline & Bangsal 1 & 69,27 & 55,69 & 33,91 & 42,90 & 21,63 & 49,02 & 25,08 \\
\hline & Bangsal 2 & 69,50 & 56,05 & 34,15 & 43,06 & 21,76 & 35,70 & 18,90 \\
\hline & Bangsal 3 & 75,67 & 65,59 & 40,30 & 47,09 & 25,20 & 46,20 & 28,60 \\
\hline & Kaliputih 1 & 77,37 & 68,24 & 42,00 & 48,21 & 26,15 & 49,20 & 30,00 \\
\hline & Kaliputih 2 & 81,13 & 74,04 & 45,74 & 50,67 & 28,24 & 50,85 & 25,99 \\
\hline & Kaliputih 3 & 79,41 & 71,38 & 44,03 & 49,55 & 27,28 & 45,20 & 24,86 \\
\hline \multirow{6}{*}{$\begin{array}{l}\text { Pegunungan } \\
\text { Selatan }\end{array}$} & Glantangan 1 & 78,71 & 70,30 & 43,33 & 49,09 & 26,89 & 48,26 & 31,75 \\
\hline & Glantangan 2 & 75,74 & 65,70 & 40,37 & 47,14 & 25,24 & 47,16 & 31,44 \\
\hline & Glantangan 3 & 96,65 & 98,05 & 61,22 & 60,84 & 36,88 & 60,80 & 44,08 \\
\hline & Tempurejo 1 & 77,27 & 68,07 & 41,89 & 48,14 & 26,09 & 47,52 & 23,76 \\
\hline & Tempurejo 2 & 61,72 & 44,02 & 26,39 & 37,96 & 17,43 & 36,14 & 23,63 \\
\hline & Tempurejo 3 & 82,79 & 76,61 & 47,40 & 51,76 & 29,16 & 53,20 & 27,93 \\
\hline
\end{tabular}

Sebagaimana dinyatakan dalam Persamaan 1.1 dan 1.2 mengikuti pola sebagai berikut:

$\mathrm{Y}_{\mathrm{fc}}=\mathrm{a}+\mathrm{bx}$

$Y_{w}=a+b x$

Berdasarkan model Persamaan 1.3 dan 1.4 maka diperoleh persamaan:

$\mathrm{Yfc}=-2,4742+0,6551(\mathrm{x}) ; \mathrm{r}=0,81$

$\mathrm{Yw}=-16,949+0,557(\mathrm{x}) ; \mathrm{r}=0,76$

Perbedaan tingkat akurasi Persamaan Karkanis dan Persamaan Baru tidak cukup signifikan $(<50 \%)$. Faktor yang mempengaruhi akurasi persamaan tersebut adalah tanah yang digunakan. Pada penelitian Karkanis (1983) persamaan yang digunakan mempunyai nilai koefisien determinasi $0,9 \approx 1$. Faktor mendasar yang membedakan hasil penelitian Karkanis (1983) dengan hasil analisis yang dilakukan adalah contoh tanah yang digunakan. Hal ini memungkinkan bahwa tanah pada daerah subtropis dan daerah tropis (Jember) memiliki karakteristik berbeda, mulai dari bahan induk pembentuk tanah, kandungan bahan organik serta faktor lingkungan yang lain. Hal ini sama dengan pendapat Grewal et al. (1990), bahwa faktor yang mempengaruhi nilai koefisien determinasi suatu persamaan seperti Persamaan 1.6 dan 1.7 yaitu daya kapilaritas, tekstur tanah, mineralogi maupun kandungan bahan organik. Menurut Intara dkk. (2011), bahan organik mempunyai peranan yang penting di dalam tanah yaitu terhadap sifat-sifat tanah. Pengaruhnya sendiri terhadap sifat listrik tanah antara lain bahan organik dapat mendorong meningkatkan daya mengikat air tanah dan mempertinggi jumlah air tersedia untuk kebutuhan tanaman.

Berdasarkan hasil analisis yang dilakukan dengan memasukkan data rata-rata kandungan air dengan metode air jenuh ke dalam Persamaan Karkanis maupun Persamaan baru yang kemudian diperoleh data seperti pada Tabel 1.1. Nilai kandungan air pada data Persamaan Karkanis, Persamaan Baru dan pengukuran Pressure Plate Apparatus terdapat beberapa yang selisihnya cukup signifikan, beberapa diantaranya adalah contoh tanah dengan tekstur loam. Tekstur tanah loam merupakan tanah dengan komposisi pasir, debu, dan klei dalam jumlah yang relatif seimbang (Tarigan dkk., 2015). 
Tabel 1.2 Total Air Tersedia pada Beberapa Tekstur Tanah

\begin{tabular}{|c|c|c|c|c|}
\hline \multirow[b]{2}{*}{ Zona } & \multirow[b]{2}{*}{ Lokasi } & \multicolumn{3}{|c|}{ Total Air Tersedia $(\Delta \theta)$} \\
\hline & & $\begin{array}{c}\text { Persamaan } \\
\text { Karkanis }\end{array}$ & Persamaan Baru & $\begin{array}{c}\text { Pengukuran Pressure } \\
\text { Plate Apparatus }\end{array}$ \\
\hline \multirow{9}{*}{ Pegunungan Raung } & Silo 1 & 19,07 & 20,79 & 12,10 \\
\hline & Silo 2 & 20,48 & 21,04 & 22,32 \\
\hline & Silo 3 & 19,79 & 20,92 & 20,88 \\
\hline & Kalisat 1 & 23,80 & 21,63 & 28,06 \\
\hline & Kalisat 2 & 20,60 & 21,06 & 18,06 \\
\hline & Kalisat 3 & 21,15 & 21,16 & 32,19 \\
\hline & Mayang 1 & 14,21 & 19,92 & 24,84 \\
\hline & Mayang 2 & 21,14 & 21,16 & 20,60 \\
\hline & Mayang 3 & 20,87 & 21,11 & 26,25 \\
\hline \multirow{11}{*}{ Pegunungan Argopuro } & Panti 1 & 27,72 & 22,33 & 33,35 \\
\hline & Panti 2 & 32,70 & 23,22 & 30,78 \\
\hline & Jelbuk 1 & 29,47 & 22,64 & 13,31 \\
\hline & Jelbuk 2 & 32,32 & 23,15 & 28,52 \\
\hline & Jelbuk 3 & 24,55 & 21,76 & 21,78 \\
\hline & Bangsal 1 & 21,78 & 21,27 & 23,94 \\
\hline & Bangsal 2 & 21,91 & 21,29 & 16,80 \\
\hline & Bangsal 3 & 25,30 & 21,90 & 17,60 \\
\hline & Kaliputih 1 & 26,24 & 22,07 & 19,20 \\
\hline & Kaliputih 2 & 28,30 & 22,43 & 24,86 \\
\hline & Kaliputih 3 & 27,35 & 22,26 & 20,34 \\
\hline \multirow{6}{*}{ Pegunungan Selatan } & Glantangan 1 & 26,97 & 22,20 & 16,51 \\
\hline & Glantangan 2 & 25,34 & 21,90 & 15,72 \\
\hline & Glantangan 3 & 36,83 & 23,96 & 16,72 \\
\hline & Tempurejo 1 & 26,18 & 22,05 & 23,76 \\
\hline & Tempurejo 2 & 17,63 & 20,53 & 12,51 \\
\hline & Tempurejo 3 & 29,21 & 22,60 & 25,27 \\
\hline
\end{tabular}

\section{Total Air Tersedia}

Total air tersedia adalah air yang tersedia bagi tanaman yaitu perbedaan antara kandungan air tanah pada kapasitas lapangan dan titik layu pemanen. Kandungan air pada kondisi kapasitas lapang dan titik layu permanen dari metode pengukuran kandungan air jenuh dan Pressure Plate Apparatus masing - masing digunakan untuk memperoleh nilai total air tersedia bagi tanaman. Total air tersedia diperoleh dengan menggunakan persamaan:

$\mathrm{AT}=\mathrm{Y}_{\mathrm{fc}}-\mathrm{Y}_{\mathrm{w}}$

Keterangan :

AT $=$ total air tersedia bagi tanaman

$\mathrm{Y}_{\mathrm{fc}} \quad=$ persamaan untuk menentukan kapasitas lapang

$\mathrm{Y}_{\mathrm{w}} \quad=$ persamaan untuk menentukan titik layu permanen

Rangkuman perbandingan total air tersedia bagi tanaman pada beberapa tekstur tanah menurut Persamaan Karkanis (1983) dan Persamaan Baru disajikan dalam Tabel 1.2. Berdasarkan data hasil perhitungan nilai total air tersedia dari Persamaan Karkanis, Persamaan Baru, dan pengukuran Pressure Plate Apparatus terdapat perbedaan (selisih $>5 \%$ kandungan air) pada beberapa data lokasi penelitian, paling banyak pada lokasi dengan tekstur tanah loam. Mayoritas data total air tersedia dengan metode pengukuran Pressure Plate Apparatus nilainya lebih rendah dibandingkan dengan data total air tersedia dengan Persamaan Karkanis maupun Persamaan Baru. Hal ini menunjukkan bahwa contoh tanah terusik lebih mudah menyerap air karena adanya kenaikan kapiler sampai titik jenuh (kandungan air maksimum) tanpa pengaruh dari manusia, dan kadar air tanah pada titik jenuh secara konsisten.
Uji Hubungan Total Air Tersedia Metode Pengukuran Kandungan Air Jenuh (Persamaan Empiris Baru) dengan Metode Pressure Plate Apparatus

Total air tersedia bagi tanaman yang diperoleh dari Persamaan Empiris Baru diuji tingkat hubungannya dengan total air tersedia bagi tanaman hasil pengukuran Pressure Plate Apparatus. Hal tersebut dilakukan untuk mengetahui kesesuaikan penggunaan metode pengukuran kandungan air jenuh untuk penetapan total air tersedia pada lokasi penelitian. Hasil analisis Grafik 1:1 dapat dilihat pada Gambar 1.1 berikut.

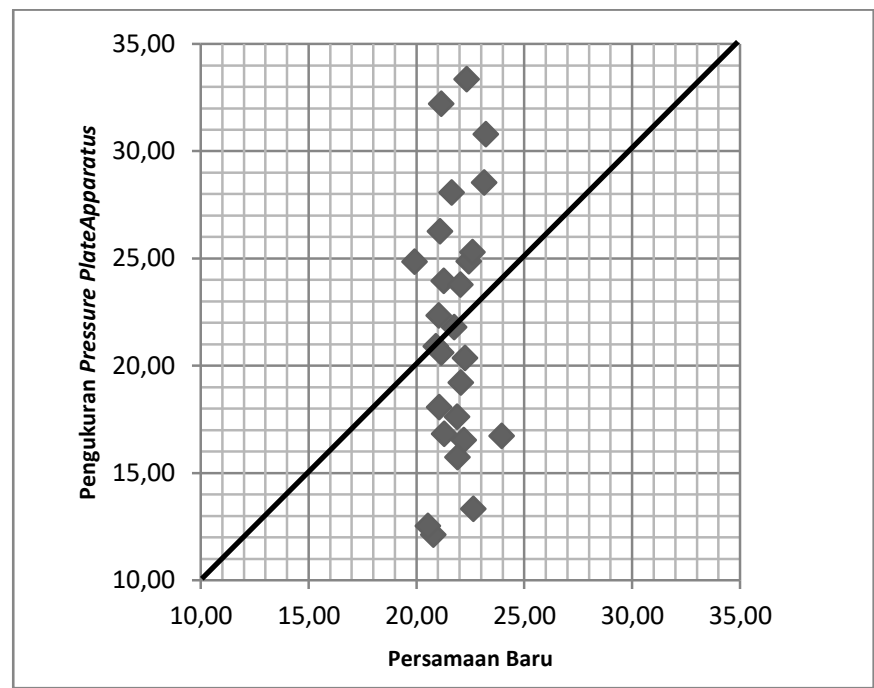

Gambar 1.1. Grafik Hubungan Total Air Tersedia Metode Air Jenuh (Persamaan Baru) dan Pressure Plate Apparatus

$y=0,9996 x+0,0064 ; R^{2}=0,0239$ 
Berdasarkan analisis tingkat akurasi data pada Gambar 1.1, dapat dilihat bahwa data total air tersedia bagi tanaman bervariasi meskipun dengan kelas tekstur yang sama. Gambar 1.1 memiliki nilai koefisien determinasi 0.0239 dan koefisien korelasi 0,154 . Hal ini berarti metode Pengukuran Kandungan Air Jenuh dengan persamaan baru tidak layak untuk diaplikasikan. Salah satu faktor yang mempengaruhi rendahnya nilai koefisien korelasi dan determinasi adalah tingkat akurasi kandungan air metode pengukuran kandungan air jenuh pada kondisi titik layu permanen (Persamaan 1.7). Sebesar $42 \%$ kandungan air kondisi titik layu permanen tidak berhubungan dengan hasil pengukuran Pressure Plate Apparatus.

Uji Hubungan Total Air Tersedia Metode Pengukuran Kandungan Air Jenuh (Persamaan Empiris Karkanis) dengan Metode Pressure Plate Apparatus

Total air tersedia bagi tanaman yang diperoleh dari Persamaan Empiris Karkanis diuji tingkat hubungannya dengan total air tersedia bagi tanaman hasil pengukuran Pressure Plate Apparatus. Hasil analisis Grafik 1:1 dapat dilihat pada Gambar 1.2 berikut.

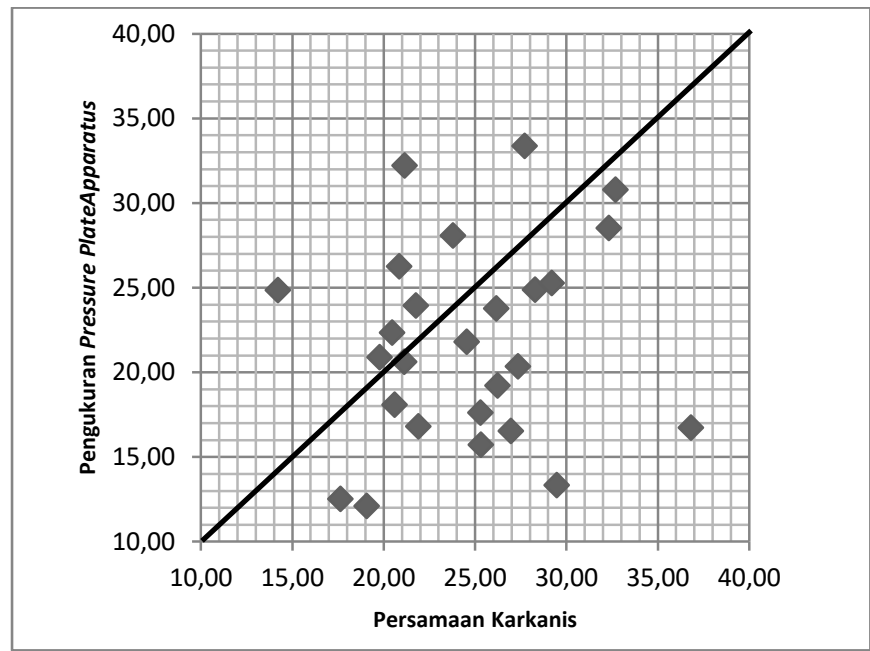

Gambar 1.2. Grafik Hubungan Total Air Tersedia Metode Air Jenuh (Persamaan Karkanis) dan Pressure Plate Apparatus

$\mathrm{y}=0,1784 \mathrm{x}+17,382 ; \mathrm{R}^{2}=0,0239$

Berdasarkan analisis tingkat akurasi data pada Gambar 1.2, dapat dilihat bahwa data total air tersedia bagi tanaman lebih bervariasi meskipun dengan kelas tekstur yang sama dibandingkan dengan Gambar 1.1. Hasil analisis pada Gambar 1.1 dan Gambar 1.2 menunjukkan bahwa kedua Persamaan 1.8 dan 1.9 memiliki nilai koefisien determinasi yang sama yaitu 0,0239 dan koefisien korelasi sebesar 0,154 . Hal ini berarti bahwa metode pengukuran air jenuh baik Persamaan Empiris Karkanis maupun Persamaan Empiris Baru tidak dapat dijadikan acuan atau dasar penentuan total air tersedia bagi tanaman.

\section{KESIMPULAN}

Berdasarkan hasil penelitian, diperoleh beberapa kesimpulan sebagai berikut:

1. Kandungan air hasil analisis dengan metode pengukuran kandungan air jenuh diregresikan dengan masing-masing data pengukuran Pressure Plate Apparatus kondisi kapasitas lapang dan titik layu permanen sehingga diperoleh persamaan empiris baru yang sesuai untuk tanah di wilayah penelitian.

$Y_{f c}=-2,4742+0,6551(x) ; R^{2}=0,6494 ; r=0,81$
$Y_{w}=-16,949+0,557(x) ; R^{2}=0,5834 ; r=0,76$

2. Penentuan total air tersedia dengan menggunakan pengukuran kandungan air jenuh tidak cukup valid/sahih, terutama disebabkan oleh rendahnya koefisien determinasi persamaan penetapan kandungan air pada kondisi titik layu permanen $\left(\mathrm{R}^{2}\right.$ $=0,5834$ )

\section{DAFTAR PUSTAKA}

Grewal, K. S., G. D. Buchan and P. J. Tonkin. 1990. Estimation of Field Capacity and Wilting Point of SomeNew Zealand Soils fom Their Saturation Percentages. Crop and Horticultural Science, 18(4) : 241-246.

Halilullah, Afandi dan H. Novpriansyah. 2015. Karakteristik Sifat Fisik Tanah pada Lahan Produksi Rendah dan Tinggi di PT Great Giant Pineapple. Agrotek Tropika, 3(2) : 278-282.

Hanafiah, K. A. 2005. Dasar-dasar Ilmu Tanah. Rajawali : Jakarta.

Imawati, S. 2009. Konflik Tambang Manga'an di Desa Pace Kecamatan Silo Kabupaten Jember 2008-2009. Universitas Jember, 1(1) : 1-121.

Intara, Y. I., A. Sapei, Erizal, N. Sembiring dan M. H. B. Djoefrie. 2011. Pengaruh Pemberian Bahan Organik pada Tanah lempung dan Lempung Berliat terhadap Kemampuan Mengikat Air. Ilmu Pertanian Indonesia, 16(2) : 130 -135.

Karkanis, P. G. 1983. Determining Field Capacity and Wilting Point Using Soil Saturation by Capillary Rise. Canadian Agricultural Engineering, 25(1): 19-21.

Lubis, K. S. 2007. Aplikasi Potensial Air Tanah. USU Repository : Medan.

Mahida, U. N. 1984. Pencemaran Air dan Pemanfaat Limbah Industri. Rajawali : Jakarta.

Siregar, S. R., Zuraida dan Zuyasna. 2017. Pengaruh Kadar Air Kapasitas Lapang terhadap Pertumbuhan Beberapa Genotipe M3 Kedelai (Glycine max L. Merr). Floratek, 12(1) : 10-20.

Tarigan, E. S. B., H. Guchi dan P. Marbun. 2015. Evaluasi Status Bahan Organik dan Sifat Fisik Tanah (Bulk Density, Tekstur, Suhu Tanah) pada Lahan Tanaman Kopi (Coffea Sp.) di Beberapa Kecamatan Kabupaten Dairi. Agroteknologi, 3(1) : 246-256.

Wahjunie, E. D., O. Haridjaja, H. Soedodo dan Sudarsono. 2008. Pergerakan Air pada Tanah dengan Karakteristik Pori Berbeda dan Pengaruh pada Ketersadiaan Air bagi Tanaman. Tanah dan Iklim, 28(1) : 15-26. 